\title{
ESTIMATION OF THE AIR QUALITY TRENDS IN ISTANBUL
}

\author{
Handan YOLSAL *
}

\begin{abstract}
Air pollution is a problem that accumulates with urbanization and threatens human health. The quality of the air we breathe is more important for the cities like İstanbul, having the busiest traffic flow and highest population in Turkey. In this work, in order to measure the air quality of İstanbul, the trend of air quality data will be estimated. Turkey, according to the data of Environment Performance Index 2014 prepared by Yale University, is listed low especially on air quality. In accordance with the agreements signed with the European Union the environmental indicators and thus our air quality should be improved. For this reason, in order to reduce air pollution a program is prepared and an Air Quality Index is formed Turkey-wide. Also in İstanbul, via many stations the air pollutants are being monitored. To increase the air quality, it is necessary to monitor the change within time of these pollutants and estimate their trend. However, the pollutants listed in the air quality index, as in all the environmental data, is a data that consists outliers and missing observations, asymmetrical, seasonal, serial dependent, do not fit the normal distribution. As of these properties, the trend analysis of the air pollutants are done via tests that are nonparametric In detecting the existence of a trend in the air quality data carrying seasonal effect the Seasonal Kendall Test is being used.

In this study the trend of air pollutants for İstanbul is tested via the monthly data gathered through 2005-2014 from different monitoring stations established by the İstanbul Metropolitan Municipality,. Among the pollutants especially in $\mathrm{SO}_{2}$ emission, in all monitoring stations, statistically significant negative seasonal trend is seen. $\mathrm{CO}$ emission is also determined to be in decrease. However PM10 and $\mathrm{NO}_{2}$ emissions are determined to be increasing in some stations. Besides, the homogeneity testing of pollutants between seasons and stations is also performed. According to this test, $\mathrm{SO}_{2}$ has a homogeneous trend between stations and seasons.
\end{abstract}

Keywords: Air pollution, Seasonal Kendall Test, Homogeneity Test.

JEL Classification: C14, O13, Q53

\footnotetext{
* Assoc. Prof. İstanbul University, Faculty of Economics, Department of Econometrics, yolsalh@istanbul.edu.tr
} 


\title{
İSTANBUL İLININ HAVA KALITTESI VERILERININ TRENDİNIN TAHMINI
}

\begin{abstract}
Özet
Hava kirliliği kentleşme ile birlikte artan ve insan sağlı̆̆ını tehdit eden bir sorundur. Soluduğumuz havanın kalitesi, Türkiye'nin en yoğun trafik akımına ve en yüksek nüfusuna sahip ili olan İstanbul ve benzeri şehirler için daha da önemlidir. Bu çalışmada İstanbul'un hava kalitesini ölçmek amaciyla, hava kalitesi verilerinin trendi tahmin edilecektir. Türkiye, Yale Üniversitesi tarafından hazırlanan Çevre Performans Endeksinin 2014 yılı verilerine göre özellikle hava kalitesi açısından alt sıralarda yer almaktadır. Avrupa Birliği ile imzalanan anlaşmalara göre çevresel göstergelerimizin ve dolayısıyla hava kalitesinin iyileştirilmesi gereklidir. Bu nedenle hava kirliğini azaltmak amacıyla bir program hazırlanmış ve Türkiye genelinde bir Hava Kalitesi Endeksi oluşturulmuştur. Hava kalitesini yükseltmek için, bu kirleticilerin zaman içinde gösterdiği değişimi inceleyerek trendini tahmin etmek gereklidir. Ancak hava kalitesi endeksinde yer alan kirleticiler, tüm çevresel verilerde olduğu gibi aykırı ve kayıp gözlemler içeren, asimetrik, mevsimsellik taşıyan, ardışık bağımlı, normal dağılıma uymayan verilerdir. Bu özellikleri nedeniyle hava kirleticilerinin trend analizleri parametrik olmayan testlerle yapılmaktadır. Mevsimsel etki taşıyan hava kalitesi verilerinde trendin varlığını denetlemekte Mevsimsel Kendall Testi kullanılmaktadır.

$\mathrm{Bu}$ çalışmada İstanbul Büyükşehir Belediyesi tarafından kurulan farklı izleme istasyonlarından 2005-2014 döneminde derlenen aylık veriler yardımıyla, İstanbul için hava kirleticilerinin trendi sınanmıştır. Kirleticilerden özellikle $\mathrm{SO}_{2}$ salınımında, bütün izleme istasyonlarında istatistiksel olarak anlamlı negatif mevsimsel trend olduğu görülmüştür. CO salınımının da düşüş eğiliminde olduğu belirlenmiştir. Ancak PM10 ve $\mathrm{NO}_{2}$ salınımının bazı istasyonlarda arttığı belirlenmiştir. Ayrıca kirleticilerin mevsimler ve istasyonlar arası homojenlik sınaması da yapılmıştır. $\mathrm{Bu}$ sınamaya göre $\mathrm{SO}_{2}$, istasyonlar ve mevsimler arasinda homojen trende sahiptir.
\end{abstract}

Anahtar kelimeler: : Hava Kirliliği, Mevsimsel Kendall Testi, Homojenlik Testi.

JEL Sınıflaması: C14, O13, Q53

\section{Introduction}

The rapidly increasing population and urbanization all around the world brought up environmental pollution. Industrialization, home waste and heating, and motor vehicle traffic caused soil, water and air pollution. Environmental pollution, especially in twentieth century, set forth as a problem that world countries struggle, also carry with it the global warming and climate change. The possibility of global climate change to reach life threatening magnitudes rendered the precautions in national scale about environmental pollution insufficient and it became inescapable for the world countries to work together. Environmental data is being observed via monitoring stations all around the world. The main objective of many monitoring programs is to detect the trend and change of the pollution levels seen in the related environmental data through time. 
There are various institutions around the world that monitor and gather environmental data. These institutions conduct research on the change in quality of air, water, soil as well as on climate change, draught, flood disasters, biological, radioactive and chemical pollution. According to the Yale University Environmental Performance Index (EPI) that is prepared biannually, Turkey stands in 66. place among 178 countries with 54.91 score. ${ }^{1}$ When the EPI scores change of Turkey for ten years is analyzed, it is seen that there is $9.03 \%$ improvement in general, however, the coast line fishing and air quality indicators are in decline. Turkey was in 74. order with 84.07 score regarding air quality indicators in EPI in 2014. However, it is on 133. rank with 87.95 score in air pollution - mean PM2.5 emission listing and on 133. rank with 67.27 score in air pollution -PM2.5 overflow listing. Thus it can be considered that Turkey fail in the EPI report and especially air pollution grades are low in this matter.

All environmental data carries some common properties. In general there is a monotonically increasing or decreasing trend in these data. In pollution data, unexpected changes in some point of time (a step- change) are also seen. Moreover, the seasonal fluctuations are added to these changes. These type of data is known to have positive correlation in time and space, and high (low) values followed by high (low) values. Besides '...less than' and '...greater than' observations, outliers and missing values are inescapable in environmental data. Environmental data has high variability. These properties of environmental data cause their statistical distributions to be skewed. In the analysis of the environmental data that diverge from the normal distribution due to all these characteristics they carry, use of parametric methods would also be inconvenient ${ }^{2}$. Thus, in general, non-parametric methods are favored in analysis of environmental data.

In the detection of the trend of environmental data, the Mann-Kendall Test is a distribution free test that can be used especially in the case of missing data and, can be used when there is no fluctuation or seasonality in the data. Thus, in testing the existence of trend in environmental data that carry inevitably by nature seasonal effects, instead of Mann-Kendall test, the Seasonal Kendall Test developed by Hirsch, Slack and $\mathrm{Smith}^{3}$ and is an intrablock method, is recommended. As the environmental data is gathered from different stations, it is not sufficient to detect trend in these data. If the trend existing in the data set is not evident in the same direction in different seasons and at different stations, it will not carry a meaning, thus homogeneity among seasons and stations should also be tested in such data. For this goal, homogeneity test recommended by Van Belle and Hughes ${ }^{4}$ is used. Whereas in estimating the trend observed in this data Sen's generalized slope estimator is used.

1 Environmental Performance Index, 2014, http://epi.yale.edu/epi/country-profile/turkey, Accessed (06.03.2015).

2 Raymond Wong, "A Procedure to Analyze Air Quality Data for the Detection of Linear Time Trends", Air Policy Branch Alberta Environment, Canada, 2010, pp. 2-3.

3 R.M. Hirsch- J. R. Slack, R.A. Smith, “Techniques of Trend Analysis for Monthly Water Quality Data”, Water Resources Research, Vol. 18, No.1, 1982, pp.107-121.

4 Gerald Van Belle - James P. Hughes, “Nonparametric Tests for Trend in Water Quality”, Water Resources Research, Vol:20, No:1, January, 1984, pp.127-136. 
In the article first of all, there is information given on air pollution, air quality index and pollutants. Following that, the non-parametric methods that are used in detection of the trend of environmental data will be introduced. Among these methods Mann-Kendall test and seasonal Kendall test that is used to measure seasonal effects as well as Sen's trend estimator will be explained. In that section also homogeneity test among seasons and stations will be explained. Later, examples of non-parametric method applications to environmental data in Turkey will be given. In fourth section, using the data of air pollutants gathered by the İstanbul Metropolitan Municipality (IMM) from ten air monitoring stations around İstanbul, testing the seasonal trend of the air quality data in between January 2005 and December 2014, homogeneity test will be done and Sen's slope coefficient will be estimated. Finally the findings will be evaluated.

\section{Air Pollution and Air Quality}

Air Pollution is the amount and density of some gases in the air composition to rise above normal and the natural composition of the air to be disrupted due to heating, transportation and economical activities of humans. ${ }^{5}$ While air was described as one of the public goods as other environmental goods in the economy literature in the beginning, with the prevalent opinion developed in recent years, is classified as global public goods. As in all public goods, it is used free of charge. Being free of charge results in air being polluted and its quality disrupted easily by the economical units. The improvement activities to prevent air pollution also place a burden on counties' economy. As a result, primarily the air pollution and all environmental problems create negative crowding out on economies. ${ }^{6}$

Air pollution, especially in metropolitans, reaches magnitudes that will affect human health. The effects of air pollution on human health is known to be seen first in the respiratory system and cause coughing, bronchitis, asthma attacks, and triggers many illnesses from heart diseases to lung cancer. Besides being related to the physiological defense mechanism of the individual, it is seen that little children and elderly are more easily affected by the air pollution. ${ }^{7}$

As of 2014, with the population of 14377018 people, İstanbul that resides $18.5 \%$ of the population of Turkey, population under 15 years of age is 3284512, while population over 65 years of age is 884872 people. ${ }^{8}$ In İstanbul which has a population density of 2767, 53854 people died in 2014. Of these losses 19955 are from circulatory system diseases and 6067 are from respiratory track

5 E.F.Ay, M.Balta, M. Çolak, H. Semercioğlu, “Hava Kirliliği ve Modellemesi”, Sakarya Üniversitesi, 2010, p.6, http:// www.sahakk.sakarya.edu.tr/documents/hava\%20kirliligi\%20ve\%20modellemesi\%20II.pdf, Accessed (18.02.2015).

6 Ergin Uzgören- Önder Yücel, "Çevre Sorunları Bağlamında Dışsal Ekonomiler ve Ekonomik Etkilerinin Analizi”, Dumlupınar Üniversitesi, Sosyal Bilimler Dergisi, Sayı:3, Kasım, 1999, pp. 97-110.

7 T. C. Çevre ve Şehircilik Bakanlığı Çevre Yönetimi Genel Müdürlüğü "Hava Kalitesinin İnsan Sağlığı Üzerine Olan Etkileri” http://www.csb.gov.tr/gm/cygm/index.php?Sayfa=sayfa\&Tur=banner\&Id=78, Accessed (24.03.2015).

8 TUIK, “Adrese Dayalı Nüfus Kayıt İstatistikleri”, http://www.tuik.gov.tr/PreTablo.do?alt_id=1059 , Accessed (28.03.2015). 
diseases. Thus air quality is greatly important for İstanbul.

The negative effect of the air pollution on environment and human health, renders improvement of air quality inevitable. Thus, all around the world, there are legal regulations done regarding control of air pollution and air quality targets are set. For this goal, there is an Air Quality Index (AQI) created that is used widely in the world. AQI is a measuring system where air in a zone is rated depending on density of air pollutants. ${ }^{9}$ In the index, each country compares the density of pollutants read from measurements done in monitoring stations with standard values they determined by themselves, and classify air quality as very good, good, fair, poor, very poor, hazardous. Index is calculated as follows;

$$
A Q I=\frac{\text { Data on Relevant Pollutant Observed in Stations }}{\text { Standard Value Related to the Pollutant }} \times 100
$$

The air quality method in Turkey is determined by the "Air Pollution Evaluation and Management Regulations" prepared in complete accordance with European Union environmental legislation. ${ }^{10}$

Air quality data being appropriate to the limits specified in regulations should be tested with trend tests. The statistical properties such as outliers and missing data that are seen in air quality data and most of the environmental data, will lead to biased estimations in case of using classical statistical methods in analysis. In the statistical analysis of the environmental data that fit fat tail distributions like Lognormal, Gama, Weibull distribution, it is befitting to turn to distribution free methods. ${ }^{11}$ Thus non-parametric methods are applied generally in testing the trend in environmental data. These methods are generally classified in to two as intrablock methods and aligned $^{12}$ rank methods. ${ }^{13}$

\section{Non-parametric Tests Applied to Environmental Data}

The Seasonal Kendall Test used widely in testing the trend for environmental data is based on studies of Mann ${ }^{14}$ and Kendall ${ }^{15}$. Mann, in order to test existence of trend in time series, recommended a unbiased and consistent test that is based on order of the data set. Later, Kendall developed the Tau $(\tau)$ test that is used to measure the correlation between two ordered data sets.

9 NSW Goverment Office of Environment \& Heritage http://www.environment.nsw.gov.au/AQMS/dataindex.htm, Accessed (07.03.2015)

10 T.C.BaşbakanlıkMevzuatıGeliştirmeve Yayın GenelMüdürlüğü, "HavaKirliliğiDeğerlendirmeveYönetimiYönetmeliği (2008)", http://www.mevzuat.gov.tr/Metin.Aspx?MevzuatKod=7.5.12188\&sourceXmlSearch=\&MevzuatIliski=0 ， Accessed (25.03.2015).

11 D.R. Helsel-R.M. Hirsch, Statistical Methods in Water Resources, Book 4: Hydrologic Analysis and Interpretation, Techniques of Water-Resources Investigations of the United States Geological Survey, 2002, p. 103.

12 Gülay B. Kıroğlu, Uygulamalı Parametrik Olmayan İstatistiksel Yöntemler, M.S.Ü. Fen-Edebiyat Fakültesi İstatistik Bölümü, 1996, p.132.

13 Gerald Van Belle-J.P. Hughes, a.g.m., s.127.

14 Henry B. Mann (1945), Nonparametric Tests Against Trend, Econometrica, Vol. 13, No. 3, 1945, pp. $245-259$.

15 Maurice G. Kendall, Rank Correlation Methods, Charles Griffin \& Company Limited, London, 2nd ed. 1975. 
The trend detection for the environmental data that do not contain seasonal fluctuations, is done by Mann-Kendall Test.

\section{I. Mann-Kendall Test}

The Mann-Kendall Test is an extension of the Kendall's rank correlation test. It claims that the slope of the linear trend equation of variable sorted by the time is zero $(\tau=0)$, in other words null hypothesis $\mathrm{H}_{0}$ is that "random variable $\mathrm{X}_{\mathrm{i}}$, does not have monotonic trend."

In the process starting with order of the data set in time as $x_{1}<x_{2}<\ldots<x_{n}$, later when $j>k$, all possible $n(n-1) / 2$ pieces of $x_{j}-x_{k}$ difference's sign is determined. The signs of mentioned difference can take values as follows;

$$
\operatorname{sgn}\left(x_{j}-x_{k}\right)=\left\{\begin{array}{c}
-1 \\
0 \\
1
\end{array} \Longleftrightarrow \quad \begin{array}{l}
\left(x_{j}-x_{k}\right)<0 \\
\left(x_{j}-x_{k}\right)=0 \\
\left(x_{j}-x_{k}\right)>0
\end{array}\right.
$$

From there the Kendall's S statistics, subtracting the number of negative differences from number of positive differences;

$$
S=\sum_{k=1}^{n-1} \sum_{j=k+1}^{n} \operatorname{sgn}\left(x_{j}-x_{k}\right)
$$

is calculated. It is known that the $\mathrm{S}$ statistic

$$
E(S)=0 \text { and } \quad \operatorname{Var}(S)=\frac{1}{18}\left[n(n-1)(2 n+5)-\sum_{j=1}^{j} t_{j}\left(t_{j}-1\right)\left(2 t_{j}+5\right)\right]
$$

fits the asymptotic normal distribution with its mean and variance value. ${ }^{16}$ The $j$ value in variance formula is the number of tied groups in the data set and $t_{j}$ is number of observations in tied group j. Tied groups are come into being due to observations that take the same value, repeat in different periods, stations or seasons. As $\mathrm{S}$, even in small samples, approaches the normal distribution ${ }^{17}, \mathrm{H}_{0}$ hypothesis is tested by standard normal variable $\mathrm{Z}$ test statistic;

$$
Z=\left\{\begin{array}{lll}
\frac{S-1}{\sigma_{S}} & & S>0 \\
0 & \Leftarrow & S=0 \\
\frac{S+1}{\sigma_{S}} & & S<0
\end{array}\right.
$$

While doing standardization in here, \pm 1 value added on $S$ value is the continuity correction

17 Henry B.Mann, Ibid, p..246-247, Maurice.G. Kendall, a.g.k., s.51. 
value. ${ }^{18}$ Thus on an $\alpha$ significance level, if $\mathrm{Z}$ value is greater than table value, the $\mathrm{H}_{0}$ hypothesis which claims that there is no linear trend, will be rejected. There the positive value of $S$ means the random variable has an increasing trend, while as opposite, its negative values show a decreasing trend. When there are no tied values in data set, using the $S$ value calculated from maximum $D=n(n-1) / 2$ pieces $x_{j}-x_{k}$ difference, Kendall's correlation coefficient $\tau$ is defined as ${ }^{19}$;

$$
\tau=\frac{S}{D}=\frac{S}{n(n-1) / 2}=\frac{S}{\left(\begin{array}{l}
n \\
2
\end{array}\right)}
$$

When there are tied values in the data set, then $\mathrm{D}$ is calculated as;

$$
D=\left[\frac{1}{2} n(n-1)-\frac{1}{2} \sum_{j=1}^{p} t_{j}\left(t_{j}-1\right)\right]^{1 / 2}\left[\frac{1}{2} n(n-1)\right]^{1 / 2}
$$

Kendall's correlation coefficient $\tau$ shows the power of the monotonic relation between $\mathrm{X}$ variable and time $(\mathrm{T})$ and is in between $-1 \leq \tau \leq+1$. If the observation numbers are $\mathrm{n}>10$, then the distribution of the Mann-Kendall statistic will approach normal distribution. ${ }^{20}$

The Mann-Kendall test which allows missing observations in data set, as it takes into account not the real observation value of the data but the placement within the ordering, in the case that there is an observation lesser than a specific detection value in the data, can be used by assigning a value smaller than the smallest value measured in the date set. ${ }^{21}$ Thus it will not be affected from censored data seen frequently in environmental data.

Mann-Kendall test should be used when there is no seasonality in the data set. It is recommended to use Seasonal Kendall test that is developed by Hirsch, Slack and Smith and it is a generalization of Mann-Kendall test in data carrying seasonality. ${ }^{22}$

\subsection{Seasonal Kendall Test}

Seasonal Kendall test that is an multivariate extension of Mann-Kendall statistics, is an intrablock test, joining $S$ statistic that is separately calculated for every $i$ season of the year in order to test trend in seasonal data. The null hypothesis of the test is that " $x_{i t}$ is independent of the time". This

18 Maurice.G.Kendall, Ibid, p.5.

19 Maurice.G.Kendall, Ibid, p.55.

20 Maurice.G.Kendall, Ibid, pp.51-55.

21 Richard O. Gilbert, Statistical Methods for Environmental Pollution Monitoring, Von Nostrand Reinhold Company Inc., New York,1987, p.209.

22 R. M. Hirsch- J. R. Slack, R.A. Smith, Ibid, pp. 107-121. 
hypothesis is examined against the alternative hypothesis "data set is not independent of the time at least for one season." in this test the number of seasons for the monthly data $m=1,2, \ldots, 12$ and for the quarterly data $m=1,2,3,4$. However, the season can be defined as days of the week or weeks of the month by the researcher. Then if the months are defined as seasons, while January is compared with only January of other years, same comparison is done for other months respectively, all the February months in the data set with each other February and again the other months with each other. These comparisons are not done between seasons. Thus Mann-Kendall S statistic, as it is calculated separately for each season in the year, $S_{m}$ for season $m$ will be as;

$$
S_{m}=\sum_{i=1}^{n_{i}-1} \sum_{j=i+1}^{n_{i}} \operatorname{sgn}\left(x_{j m}-x_{i m}\right) \quad m=1,2, \ldots, M \text { (numbers of seasons) }
$$

In the large samples $S_{m}$ statistics of the seasons will approach the normal distribution with ${ }^{23}$;

$$
E\left(S_{m}\right)=0 \text { ve } \operatorname{Var}\left(S_{m}\right)=\frac{n_{m}\left(n_{m}-1\right)\left(2 n_{m}+5\right)-\sum_{j=1} t_{j}\left(t_{j}-1\right)\left(2 t_{j}+5\right)}{18}
$$

Here $t_{j}$ shows tied group $j$ 's size. Thus adding up the $S_{m}$ values calculated for each season, global $S_{k}$ statistic will be reached.

$$
S_{k}=\sum_{m=1}^{M} S_{m}
$$

Thus global $\tau$ value is calculated. Since global $\tau$ will be more sensitive than monthly statistics, while no monthly trend is significant, the global trend can be significant. ${ }^{24}$

In Seasonal Kendall test $S_{k}$; while covariance between different seasons is $\operatorname{Cov}\left(\mathrm{S}_{\mathrm{m}} \mathrm{S}_{\mathrm{h}}\right)$,

$$
E\left(S_{k}\right)=0 \text { and } \operatorname{Var}\left(S_{k}\right)=\sum_{m=1}^{m} \operatorname{Var}\left(S_{m}\right)+\sum_{\substack{m, h \\ m \neq h}} \operatorname{Cov}\left(S_{m} S_{h}\right)
$$

Approach normal distribution. $S_{k}$ is standardized as follows,

23 R. M. Hirsch- J. R. Slack, R.A. Smith, Ibid, pp.108-109.

24 Jie Tian- G.C.J. Fernandez, "Seasonal Trend Analysis of Monthly Water Quality Data", The Western Users of SAS Software, Los Angeles, US, 1999, pp.1-6. 


$$
Z=\left\{\begin{array}{lr}
\frac{S_{k}-1}{\sigma_{S_{k}}} & S_{k}>0 \\
0 & \Leftarrow S_{k}=0 \\
\frac{S_{k}+1}{\sigma_{S_{k}}} & S_{k}<0
\end{array}\right.
$$

Z statistic calculated, then if $\left|Z_{S_{k}}\right|<Z_{\text {Critic }}$, then $\mathrm{H}_{0}$ hypothesis will be accepted. While calculating standard $Z$ value, for $n \geqslant 10$ continuity correction is not necessary. ${ }^{25}$ While there is a serial dependence in data set, it would be $\operatorname{Cov}\left(\mathrm{S}_{\mathrm{m}} \mathrm{S}_{\mathrm{h}}\right) \neq 0$, Seasonal Kendall test statistic is modified by Hirsch and Slack (1984), as follows ${ }^{26}$

$$
\operatorname{Var}\left(S_{k}\right)=\sum_{m=1}^{M} \operatorname{Var}\left(S_{m}\right)
$$

\subsection{Homogeneity Testing}

In order to consider that the relevant data has seasonal trend, trend should be the same in all seasons. Likewise, if the data is gathered in a specific region from more than one monitoring stations, in order to mention that the data has monotonic trend, it should be test that the trend is the same direction in all seasons and stations. ${ }^{27}$ Homogeneity testing both in between seasons and in between stations is performed by $\chi_{\text {hom }}^{2}$ test suggested by Van Belle and Hughes. ${ }^{28}$ According to this, the homogeneity testing among seasons is conducted with $\chi_{\text {hom }}^{2}$ statistic that is as follows,

$$
\chi_{\text {hom }}^{2}=\chi_{\text {total }}^{2}-\chi_{\text {trend }}^{2}=\sum_{i=1}^{M} Z_{i}^{2}-M \bar{Z}^{2} \quad i=1,2, \ldots, \mathrm{M} \text { (numbers of seasons) }
$$

Since $\chi_{\text {hom }}^{2}$ has chi-square distribution with M-1 degrees of freedom (df), if $\chi_{\text {hom }}^{2}$ exceeds $\chi_{\text {critic }}^{2}$ value with $\mathrm{M}-1 \mathrm{df}$ and a significance level, null hypothesis " $\mathrm{H}_{0}$ : All seasonal trends are in the same direction." is rejected and it is concluded that seasonal correlation coefficients are not significant. In that case, instead of seasonal Kendall test, the Mann-Kendall test should be applied for each season separately. ${ }^{29}$ If $\chi_{\text {hom }}^{2}<\chi_{\text {critic }}^{2}$, then the statistic $\chi_{\text {trend }}^{2}=M \bar{Z}^{2}$ has chi-square distribution with $1 \mathrm{df}$ to test that the global trend is significant in all seasons.

Similarly if only among the stations the homogeneity will be tested, the Mann-Kendall statistics calculated from each station is used. According to this while the Mann-Kendall statistic $S_{j}$ is calculated for station $j$, 


$$
Z_{j}=\frac{S_{j}}{\sqrt{\operatorname{Var}\left(S_{j}\right)}} \quad \text { and } \quad \bar{Z}=\frac{1}{K} \sum_{j=1}^{K} Z_{j}
$$

values are calculated, and $\mathrm{H}_{0}$ "the trend of all stations is in the same direction" hypothesis is tested by $\chi_{\text {hom }}^{2}$,

$\chi_{\text {hom }}^{2}=\chi_{\text {total }}^{2}-\chi_{\text {trend }}^{2}=\sum_{j=1}^{K} Z_{j}^{2}-K \bar{Z}^{2} \quad j: 1, \ldots, K$ (numbers of stations)

that fits to $\chi^{2}$ distribution with K-1 df. So if $\chi_{\text {hom }}^{2}>\chi_{\text {critic }}^{2}$ then $\mathrm{H}_{0}$ hypothesis is rejected and it can be considered the direction of the trends in the stations are different. Thus there will be no regional opinion regarding the direction of the trend would not be suggested. In that case, the trends of the stations can only be examined individually. In the opposite, $\chi_{\text {hom }}^{2}<\chi_{\text {critic }}^{2}$ then the directions of trends in the stations will be accepted as homogeneous, thus the statistic $\chi_{\text {trend }}^{2}=K \bar{Z}^{2}$ fits the $\chi^{2}$ distribution which has $1 \mathrm{df}$ to test that the global trend is significant in all stations.

The validity of $\chi^{2}$ homogeneity test depends on the $Z_{j}$ value, calculated for each station, has a normal distribution. Also $Z_{j}$ values should be independent, in other words, the data collected from different stations should be uncorrelated.

In order to test the homogeneity of the trend both among seasons and stations together, again the $\chi^{2}$ homogeneity test, that is developed similar to two way variance analysis by Van Belle and Hughes, is used, ${ }^{30}$

$\mathrm{H}_{01}: \tau_{1 .}=\tau_{2 .}=\ldots=\tau_{m .} \quad$ (Trends are homogenous in all seasons.)

$\mathrm{H}_{02}: \tau_{.1}=\tau_{.2}=\ldots=\tau_{. k} \quad$ (Trends are homogenous in all stations.)

$\mathrm{H}_{03}: \tau_{i j}-\tau_{i .}-\tau_{. j}+\tau=$ constants (The interaction between stations and seasons is constant.)

$\mathrm{H}_{04}: \tau . .=0 \quad$ (Without an interaction between seasons, stations, and stations and seasons, there is no global trend.)

the joint hypothesis' as above are tested. ${ }^{31}$ For this in every station for each season separately

$Z_{i j}=\frac{S_{i j}}{\sqrt{\operatorname{Var}\left(S_{i j}\right)}} \quad i=1,2, . ., M$ (seasons) and $j=1,2, \ldots, K$, (stations)

30 Gerald Van Belle- J.P. Hughes, Ibid, p.131.

31 Gerald Van Belle- J.P. Hughes, Ibid, p.131. 
$\bar{Z}_{i .}=\frac{1}{K} \sum_{j=1}^{K} Z_{i j}, \quad i=1,2, \ldots, M \quad$ mean over $K$ stations for the $i^{\text {th }}$ season

$\bar{Z}_{. j}=\frac{1}{M} \sum_{i=1}^{M} Z_{i j} \quad j=1,2, . ., K \quad$ mean over $M$ seasons for $j^{\text {th }}$ station

$\bar{Z} . .=\frac{1}{K M} \sum_{i=1}^{M} \sum_{j=1}^{K} Z_{i j} \quad$ global mean over $K M$ stations and seasons

values are calculated then relevant statistics are calculated as follow; ${ }^{32}$

$$
\begin{aligned}
& \chi_{\text {hom }}^{2}=\chi_{\text {total }}^{2}-\chi_{\text {trend }}^{2}=\sum_{i=1}^{M} \sum_{j=1}^{K} Z_{i j}^{2}-K M \bar{Z}_{. .}^{2} \\
& \chi_{\text {season-stat }}^{2}=\chi_{\text {hom }}^{2}-\chi_{\text {season }}^{2}-\chi_{\text {stat. }}^{2}=\sum_{i=1}^{M} \sum_{j=1}^{K} Z_{i m}^{2}-K \sum_{j=1}^{M} \bar{Z}_{i .}^{2}-M \sum_{i=1}^{K} \bar{Z}_{. j}^{2}+K M \bar{Z}_{. .}^{2}
\end{aligned}
$$

Here, if the $\chi_{\text {season }}^{2}, \chi_{\text {stat. }}^{2}$ and $\chi_{\text {season-stat }}^{2}$ tests, respectively, are insignificant with $(\mathrm{K}-1),(\mathrm{M}-1)$ and $(\mathrm{K}-1)(\mathrm{M}-1) \mathrm{df}$, the global trend with $1 \mathrm{df}$ should be tested by $\chi_{\text {trend }}^{2}=K M \bar{Z}_{\text {.. }}^{2}$ statistic. If $\chi_{\text {season }}^{2}$ is significant, but $\chi_{\text {stat. }}^{2}$ is insignificant, with $1 \mathrm{df}$

$$
K \bar{Z}_{i .}^{2} \quad i=1,2, \ldots, M \text { numbers of seasons }
$$

difference of trend direction, that not in different stations but in different seasons, in different directions there is significant trend, thus via calculating $M$ pieces of seasonal statistics value in each season, should be tested. In the opposite if $\chi_{\text {stat. }}^{2}$ is significant but $\chi_{\text {season }}^{2}$ is insignificant, there are trends in different directions not in seasons but in different stations. In this case calculating the statistics of $\mathrm{K}$ station, again with 1 degree of freedom, significance of

$$
M \bar{Z}_{. j}^{2} \quad j=1,2, \ldots, K \text { number of stations }
$$

trend direction should be tested. If both for stations and seasons of the $\chi^{2}$ statistics are significant or the interaction value $\chi_{\text {season-stat }}^{2}$ is significant, then global trend test $\left(\chi_{\text {trend }}^{2}\right)$ should not be conducted.

32 Gerald Van Belle- J.P. Hughes, Ibid, p.131, Richard O. Gilbert, Ibid, p.232. 


\subsection{Sen's Trend Estimators}

In linear trend estimations done by parametric methods, in the case that there are outliers and missing data in data set, it is known that the slope is estimated as biased from its real value. ${ }^{33}$ Trend estimator that is suggested by Sen and is an extension of Theil test, is not so much affected from outliers and missing data. The Sen's slope estimator $\left(\hat{\beta}_{1}\right)$, closely related with Mann-Kendall test, is a median of a series consisting of $Q$ values calculated as

$$
Q=\frac{x_{j}-x_{i}}{j-i}
$$

separately for each station over $\mathrm{N}^{\prime}=\mathrm{n}(\mathrm{n}-1) / 2$ pairs of observations. Here $x_{j}$ and $x_{i}$ values are values of the relevant series in the $j^{\text {th }}$ and $i^{\text {th }}$ periods when $j>i$. While observation count $\mathrm{n}>10$, Sen's slope estimator would fit the normal distribution. ${ }^{34}$

While it is recommended to use at least five years of data in monthly basis to be used in monotonic trend analysis of environmental data, at least two years of data, before and after the relevant event, in monthly basis will be necessary for stepwise trend analysis. ${ }^{35}$

The slope of data carrying seasonality is found via generalization of the Sen's slope estimator. In this case, first of all $N_{i}$ pieces Q value is calculated as

$$
Q_{i}=\frac{x_{i l}-x_{i k}}{l-k}
$$

for each $i^{\text {th }}$ season. Here when $l>k, x_{i l}$ is the data that belongs to $l^{\text {th }}$ year $i^{\text {th }}$ season and $x_{i k}$ is the data that belongs to $k^{\text {th }}$ year $i^{\text {th }}$ season. Thus for $\mathrm{M}$ season $N_{1}^{\prime}+N_{2}^{\prime}+\ldots+N_{M}^{\prime}=N^{\prime}$ pieces of slopes are ordered and the median value of these ordered slopes will be the seasonal slope estimator.

\section{Review of the Literature}

It is known that the non-parametric methods applied on environmental data in Turkish literature, was first applied on water quality data. The trends of water quality in Yeşilırmak Basin were detected by Y. İçağa and N. Harmancıoğlu. ${ }^{36}$ A similar study is performed by S. Kalaycı and E. Kahya. ${ }^{37}$ In this study, the existence of a linear trend in surface water quality of rivers of Susurluk Basin was tested with again Seasonal Kendall test and other non-parametric tests. Also in this study, Van Belle and Hughes homogeneity tests were used. In another study of S. Kalayc1

33 Richard O. Gilbert, Ibid, p.217-218.

34 Richard O. Gilbert, Ibid, p.217-218.

35 Robert M. Hirsch, Statistical methods and sampling design for estimating step trends in surface water quality. Water Resources Research, 24, 1988, pp.493-503.

36 Y. İçağa- N. Harmancıoğlu, “Yeşilırmak Havzasında Su Kalite Eğilimlerinin Belirlenmesi”, TMMOB, Türkiye İnşaat Mühendisliği 13. Teknik Kong, 1995, pp.481-497.

37 S. Kalaycı -E. Kahya, “Susurluk Havzası Nehirlerinde Su Kalitesi Trendlerinin Belirlenmesi”, Tr. J. of Engineering and Environmental Science, 22, 1988, pp.503- 514. 
and E. Kahya, monthly flow data of twenty six river basins in Turkey, was examined with nonparametric tests for a thirty one year period. ${ }^{38} \mathrm{~B}$. Önöz and M. Bayazit ${ }^{39}$, examined yearly flow data of hundred and seven stations in various river basins in Turkey for a twenty five year period, and tested their trends with $\mathrm{t}$ test and Mann-Kendall test.

Another study where non-parametric tests were used, was the study on temperature trends of Kahramanmaraş by F. Cosun and M. Karabulut. ${ }^{40}$ There was significant increase observed especially in winter and summer months in the Kahramanmaraş.

In the compilation by $\mathrm{H}$. Bayram ${ }^{41}$, in the values of air pollutants, there is an improvement detected in recent years. T. Elbir, A. Müzezzinoğlu, A. Bayram, ${ }^{42}$ investigated the appropriation of five basic air pollutant emissions to European Union and World Health Organization criteria, in İstanbul, Ankara and İzmir as well as in all Turkey in years between 1985-2005, determined that the pollutant emission especially in winter months, are above limit values. M. Tayanç, M. Karaca, O. Yenigün ${ }^{43}$, measured the trend of the $\mathrm{SO}_{2}$ and $\mathrm{PM}$ indicators in 54 stations in urban and rural regions in the period between 1951-1990 by the help of Kendall's rank correlation coefficient. Also it estimated the linear temperature trend. M. Tayanç, ${ }^{44}$ worked on historical processes of Lagrange and Euler based models that are used in air quality modeling in Turkey.

U. Malak, K. Alp ${ }^{45}$, monitored the PM10 and PM 2.5 observations at three stations in Anatolian side of İstanbul for a year as weekdays and weekend and showed that the air quality data have medium level pollution values. In a similar study is performed by O. Gümüş et.al ${ }^{46}$. In this study the statistical properties of the PM10 and PM2.5 values of provinces in Marmara region are examined and while there is a difference found between weekdays and weekend mean emissions of PM10, there was no difference shown in mean emissions of PM2.5.

38 S. Kalayc1- E.Kahya, "Trend analysis of streamflow in Turkey”, Journal of Hydrology, 289, 2004, pp.128-144.

39 B. Önöz- M. Bayazıt, “The Power of Statistical Tests for Trend Detection”, Turkish Journal of Engineering and Environmental Sciences, TÜBİTAK, 27, 2003, pp.247-251.

40 F. Cosun- M. Karabulut, "Kahramanmaraş’ta Ortalama, Minimum ve Maksimum Sıcaklıkların Trend Analizi”, Türk Coğrafya Dergisi, Sayı 53, 2009, pp.41-50.

41 H. Bayram, “Türkiye’de Hava Kirliliği Sorunu: Nedenleri, Alınan Önlemler ve Mevcut Durum”, Toraks Dergisi,6(2), 2005, pp.159-165.

42 T. Elbir- A. Müzezzinoğlu- A. Bayram, "Evaluation of Some Air Pollution Indicators in Turkey", Environmental International, 26, 2000, pp.5-10.

43 Mete Tayanç- M. Karaca- O. Yenigün, “Annual and Seasonal Air Temperature Trend Patterns of Climate Change and Urbanization Effects in Raletion to Air Pollutants in Turkey", Journal of Geophysical Research, Vol. 102, No. D2, 1997, pp.1909-1919.

44 Mete Tayanç, “Türkiyede Hava Kalitesi Modellemesi”, Hava Kirliliği Araştırma Dergisi, 2, 2013, pp.112122.

45 U. Malak, K. Alp, “İstanbul Anadolu Yakası Hava Kirliliğinin $\mathrm{PM}_{10}$ ve $\mathrm{PM}_{2.5}$ açısından Değerlendirilmesi”, 6. Ulusal Hava Kirliliği ve Kontrolü Sempozyumu,7-9 Ekim 2015, İzmir, pp.515-525.

46 O. Gümüş ve diğerleri, "Marmara Bölgesi Hava Kalitesinin İstatistiksel Yöntemlerle Analizi”, 6. Ulusal Hava Kirliliği ve Kontrolü Sempozyumu, 7-9 Ekim 2015, İzmir, pp.780-793. 


\section{Examination of Air Quality Data of İstanbul}

The fight against air pollution, studies for measuring the pollution rate of air and creating an index related to air quality is rather old. In 2007 ten monitoring stations by the IMM was established for this purpose. These stations are Aksaray, Alibeyköy, Beşiktaş, Esenler, Kadıköy, Kartal Sarıyer, Ümraniye, Üsküdar and Yenibosna stations. The Aksaray station among these was called as Saraçhane station in 2005 and 2006. The name of the station is changed as Aksaray as of 2007. However, the location of the station is the same. The stations installed to follow the quality of environmental indicators are often chosen without information on pollution sources. ${ }^{47}$ However, Metropolitan Municipality took into account the topological structure, climate conditions, placement of industrial zones, status of buildings and residential areas, vehicle traffic, population distribution, natural gas distribution and meteorological data, and aimed that the chosen point has representative qualities. ${ }^{48} \mathrm{IMM}$ measures the air pollutants $\mathrm{SO}^{2}$, Particulate matter $\left(\mathrm{PM}_{10}\right)$, $\mathrm{CO}, \mathrm{NO}, \mathrm{NO}_{\mathrm{x}}, \mathrm{NO}_{2}, \mathrm{THC}$, Methane $\left(\mathrm{CH}_{4}\right), \mathrm{MHC}$ and $\mathrm{O}_{3}$.

In this study, among the pollutants the ones published rather regularly, $\mathrm{SO}_{2}, \mathrm{PM}_{10}, \mathrm{CO}, \mathrm{NO}_{2}$ data are examined monthly through January 2005 and December 2014 period. As there were many missing data for pollutants in many of the stations, year 2015 is not included in the analysis. The measurements on pollutants are conducted by IMM, over arithmetic mean of the values of twenty four hours of previous day. ${ }^{49}$

During the research period it is seen that observation values are missing in many of the monitoring stations. $\mathrm{SO}_{2}$ is missing 15 observations in Aksaray station and 8 observations Ümraniye station. The station with most missing observations for PM10 is Alibeyköy. CO measurements are rather irregular. For CO there is 47 missing observations in question at Kartal and Saryer, 50 as such at Ümraniye. These stations were not included in CO trend analysis. Again in Kartal, Sariyer, Üsküdar and Yenibosna, there are no observations for $\mathrm{NO}_{2}$. The district where all the pollutants are measured regularly is Beşiktaş.

It is known that the emission of $\mathrm{SO}_{2}$ among air pollutants is caused often by coal and fuel-oil like fuels used for heating. According to European Union and World Health Organization, the daily limit overflow value for $\mathrm{SO}_{2}$ emission is $125 \mu \mathrm{g} / \mathrm{m}^{3}$ and the limit overflow should be limited to three times a year at maximum. ${ }^{50}$ Through the research period, there were no limit overflows in $\mathrm{SO}_{2}$ emission in İstanbul. PM10 is generally caused by fuels, construction and industrial activities, and dust that wind unearths. Regarding human health the daily mean PM10 value should not exceed $50 \mu \mathrm{g} / \mathrm{m}^{3}$ more than 35 times in a year. Whereas yearly mean PM10 value should not exceed $40 \mu \mathrm{g} / \mathrm{m}^{3} .^{51}$ The Africa desert winds that are mainly effective especially in Aegean and

47 T. L. Schertz- R. B. Alexander, D. J. Ohe, “The Computer Program Estimate Trend ( Estrend)”, A System For The Detection in Water-Quality Data, U.S. Geological Survey, 1991, p.5.

İBB,www.ibb.gov.tr, Accessed (25.02.2015).

İBB, www.ibb.gov.tr, Accessed (25.02.2015).

European Commision, http://ec.europa.eu/environment/air/quality/standards.htm, Accessed (20.03.2015).

European Environment Agency www.eea.europa.eu, Accessed (12.03.2015). 
Marmara Regions and Middle East desert winds that are mainly effective in Southeastern Region are also a main source for PM10 in Turkey. ${ }^{52} \mathrm{CO}$ is a pollutant caused by mainly insufficient burning of the fossil fuels and especially from motor vehicle traffic, and daily $\mathrm{CO}$ emission for 8 hour means must be at maximum $10 \mathrm{mg} / \mathrm{m}^{3}$ according to European Union. ${ }^{53}$ The most important factor in production of $\mathrm{NO}_{2}$ gas is the motor vehicles and thermal power plants. $\mathrm{NO}_{2}$ gas causes respiratory tract diseases. Even a brief exposure to $\mathrm{NO}_{2}$ affects lung functions. $\mathrm{NO}_{2}$ emission should not exceed mean $200 \mu \mathrm{g} / \mathrm{m}^{3}$ more than eighteen times. Yearly mean of $\mathrm{NO}_{2}$ must not exceed $40 \mu \mathrm{g} / \mathrm{m}^{3}{ }^{54}$

The descriptive statistics of pollutants are calculated and it is seen that only PM10 emission observed at Ümraniye station fits the normal distribution at the $1 \%$ level according to Shapiro Wilk normality test, ${ }^{55}$ whereas no other pollutants observed in any other stations fit the normal distribution. It is observed that the distribution of the pollutants is mainly skewed to right and there are missing observations in data set. For this reason, the trend of air pollutants is investigated by non-parametric tests. In the case that in the observations of the pollutants gathered from different stations, there is missing data, firstly the estimate of these values should interpolate. Here, the interpolation process is done by assuming that the past data is stationary. However if the missing values in data set are not too much and occur randomly, the analysis can be continued with the missing data. ${ }^{56}$ The simplest way for interpolation, is to give the mean or median value of the same months included in the research period to the month with missing observation. Here, while the values of the pollutants are gathered by IMM, as the twenty four hour arithmetical mean is given, interpolation taking the arithmetical means as basis. After completion of the missing values, first of all Mann-Kendall test was applied to all pollutants and the Sen's Trend estimator and $\mathrm{Z}$ values are calculated. Results are given in Table 1.

52 C. Dündar, K. Oğuz, G. Güllü, “Toz Taşınımı Mekanizmalarındaki Farklılıklar: İki Farklı Toz Taşınımı Olayı”, 6. Ulusal Hava Kirliliği ve Kontrolï Sempozyumu, 7-9 Ekim 2015, İzmir, pp.18-28.

53 http://ec.europa.eu/environment/air/quality/standards.htm, Accessed (20.03.2015).

54 http://ec.europa.eu/environment/air/quality/standards.htm Accessed (20.03.2015).

55 S. S. Shapiro, Wilk, M. B., "An Analysis of Variance Test for Normality (Complete Samples)”, Biometrika, 52(3/4), Dec., 1965, pp. 591-611.

56 Janina Mozejko, "Detecting and Estimating Trends of Water Quality Parameters", Water Quality Monitoring and Assessment, Ed. K. Voudouris, D, Voutsa, www.intechopen.com ,2012, p. 97, Accessed (15.03.2015). 
Table I. Sen's Estimators and Mann-Kendall Correlation Coefficients of Air Pollutants (January 2005 -December 20I4)

\begin{tabular}{|c|c|c|c|c|c|c|}
\hline & \multicolumn{3}{|c|}{$\mathrm{SO}_{2}\left(\mu \mathrm{g} / \mathrm{m}^{3}\right)$} & \multicolumn{3}{|c|}{$\operatorname{PM10}\left(\mu \mathrm{g} / \mathrm{m}^{3}\right)$} \\
\hline Stations & Z & $\operatorname{MK}(\tau)$ & Sen & $\mathrm{Z}$ & $\operatorname{MK}(\tau)$ & Sen \\
\hline Aksaray & -8.47 & $-0.52^{*}$ & -1.33 & -0.52 & -0.03 & -0.25 \\
\hline Alibey. & -6.60 & $-0.41^{*}$ & -0.96 & -1.73 & $-0.11^{\star \star \star}$ & -0.95 \\
\hline Beşiktaş & -10.42 & $-0.64^{\star}$ & -1.78 & -4.44 & $-0.27^{\star}$ & -1.87 \\
\hline Esenler & -8.06 & $-0.50^{*}$ & -1.20 & -1.43 & -0.09 & -0.90 \\
\hline Kadıköy & -5.83 & $-0.36^{*}$ & -0.55 & 0.00 & 0.00 & 0.00 \\
\hline Kartal & -8.23 & $-0.51^{*}$ & -1.41 & -2.60 & $-0.16^{*}$ & -1.89 \\
\hline Sarıer & -5.02 & $-0.31^{*}$ & -0.60 & -3.05 & $-0.19^{*}$ & -1.41 \\
\hline Ümran. & -6.34 & $-0.39^{\star}$ & -0.65 & 1.21 & 0.07 & 0.51 \\
\hline Üsküdar & -5.27 & $-0.32^{\star}$ & -0.63 & 1.62 & 0.10 & 0.73 \\
\hline \multirow[t]{2}{*}{ Yenibos. } & -8.65 & $-0.53^{*}$ & -1.38 & -0.13 & -0.01 & 0.00 \\
\hline & \multicolumn{3}{|c|}{$\mathrm{CO}\left(\mu \mathrm{g} / \mathrm{m}^{3}\right)$} & \multicolumn{3}{|c|}{$\mathrm{NO}_{2}\left(\mu \mathrm{g} / \mathrm{m}^{3}\right)$} \\
\hline İstasyon & Z & $\operatorname{MK}(\tau)$ & Sen & $\mathrm{Z}$ & $\operatorname{MK}(\tau)$ & Sen \\
\hline Aksaray & -7.90 & $-0.49^{*}$ & -59.82 & 0.48 & 0.03 & 0.23 \\
\hline Alibey. & -1.70 & $-0.11^{\star * *}$ & -13.47 & 1.17 & 0.07 & 0.56 \\
\hline Beşiktaş & -7.47 & $-0.46^{*}$ & -49.71 & 4.73 & $0.29^{*}$ & 3.80 \\
\hline Esenler & -2.24 & $-0.14^{* *}$ & -16.20 & 2.37 & $0.15^{* *}$ & 1.44 \\
\hline Kadıköy & -5.04 & $-0.31^{*}$ & -48.65 & -2.67 & $-0.17^{*}$ & -1.82 \\
\hline Kartal & ----- & ----- & ---- & ---- & ----- & ---- \\
\hline Sarıyer & ----- & ----- & ----- & ----- & ----- & ----- \\
\hline Ümran. & ----- & ----- & ----- & 3.31 & $0.20^{*}$ & 1.64 \\
\hline Üsküdar & -1.97 & $-0.12^{*}$ & -15.76 & ----- & ----- & ---- \\
\hline Yenibos. & -0.54 & -0.03 & -3.37 & ----- & ----- & ----- \\
\hline
\end{tabular}

Shows the Mann-Kendall correlation coefficients and Sen's slope estimators are significant with *1\%, with ${ }^{* *} 5 \%$ and with ${ }^{* * *} \% 10$ 
According to the trend testing, $\mathrm{SO}_{2}$ emission in 2005-2014 periods in all the stations has statistically significant negative trend. Fastest decrease is seen in Beşiktaş district. In this district, the Mann-Kendall correlation coefficient shows that $\mathrm{SO}_{2}$ emission is negative relation in -0.64 over time. Mann-Kendall statistic being significant shows that at the same time Sen slope estimator is significant too. $\mathrm{SO}_{2}$ pollutans, according to Sen's slope estimators, has a statistically significant negative trend in all stations. Sen's slope shows the slope in unit time.

PM10 has statistically significant negative trend in Alibeyköy, Beşiktaş Kartal and Sarıer. However correlations are rather weak. The strongest $\tau$ correlation coefficient is about -0.27 at Beşiktaş station. The relation of PM10 over time in other stations with significant trend is weaker than Beşiktaş. In Aksaray, Esenler, Kadıköy, Ümraniye, Üsküdar and Yenibosna, it is observed that the pollutant does not carry a trend.

When we came to $\mathrm{CO}$ emission trend detection, first of all, as there are too much missing values in Kartal, Sariyer and Ümraniye stations, these stations were left out of research as it was not possible to perform interpolation. It is concluded that there is no significant monotonic trend in Yenibosna station where CO emission was detected. In Aksaray, Alibeyköy, Beşiktaş, Esenler, Kadıköy and Üsküdar that have significant monotonic trend, it is in decrease. The greatest decrease in CO emission is in Aksaray and Başiktaş stations with negative trend around 46-49\%. The correlation coefficients in other stations are very weak. As in CO pollutant, in $\mathrm{NO}_{2}$ pollutant, the data is also very irregular. There is not data for $\mathrm{NO}_{2}$ in Kartal, Sarıyer, Üsküdar and Yenibosna stations. Thus the trend testing was not done in mentioned stations. $\mathrm{NO}_{2}$ does not have significant monotonic trends over time in Aksaray and Alibeyköy stations. Among others, in Beşiktaş, Esenler and Ümraniyede $\mathrm{NO}_{2}$ emission have significat positive trend. The highest correlation is in Beşiktaş and is only \%29. $\mathrm{NO}_{2}$ emission has statistically significant negative trend in Kadıköy

It is not sufficient for trends of air quality data at stations to be significant. Also trend should be towards same direction in all the stations. Thus the homogeneity of the directions of the trends at different stations should be tested. For this aim, at the stations that Mann-Kendall correlation coefficients of the pollutants over the time are statistically significant, respectively

$\mathrm{H}_{01}: \mathrm{SO}_{2}$ emission have same negative trend in all stations.

$\mathrm{H}_{02}$ : PM10 emission have same negative trend in Alibeyköy, Beşiktaş, Kartal and Sarıyer.

$\mathrm{H}_{03}$ : $\mathrm{CO}$ emission have same negative trend in Aksaray, Alibeyköy, Beşiktaş, Esenler, Kadıköy and Üsküdar.

$\mathrm{H}_{04}: \mathrm{NO}_{2}$ emission have same positive trend in Beşiktaş, Esenler and Ümraniye.

Hypotheses are tested according to formula (15). The results of homogeneity test are given in Table 2. The $Z_{\mathrm{i}}$ values used in the calculation of the $\chi^{2}$ values in this table are calculated without using correction factor according to Van Belle-Hughes approach. 
Table 2. Homogeneity Testing Among Stations for Air Pollutants

\begin{tabular}{|c|c|c|c|c|c|c|c|c|}
\hline \multirow[b]{2}{*}{ Source } & \multicolumn{2}{|c|}{$\begin{array}{c}\mathrm{SO}_{2} \\
(-) \text { Slope }\end{array}$} & \multicolumn{2}{|c|}{$\begin{array}{c}\text { PM10 } \\
\text { (-) Slope }\end{array}$} & \multicolumn{2}{|c|}{$\begin{array}{c}\text { CO } \\
\text { (-) Slope }\end{array}$} & \multicolumn{2}{|c|}{$\begin{array}{c}\mathrm{NO}_{2} \\
(+) \text { Slope }\end{array}$} \\
\hline & $\chi^{2}$ & d.f. & $\chi^{2}$ & d.f. & $\chi^{2}$ & d.f. & $\chi^{2}$ & d.f. \\
\hline Total & 558.82 & 10 & 38.847 & 4 & 155.45 & 6 & 38.98 & 3 \\
\hline Homogeneity & $27.27^{\star}$ & 9 & 3.845 & 3 & $39.9^{*}$ & 5 & 2.82 & 2 \\
\hline Trend & 531.55 & 1 & 35.002 & 1 & 115.55 & 1 & 36.16 & 1 \\
\hline
\end{tabular}

Since $\chi_{\text {hom }}^{2}>\chi_{\alpha=0.01}^{2}$, Trends are heterogeneous at all stations at ${ }^{*} 1 \%$ significance level

According to this, " $\mathrm{SO}_{2}$ emission has the same negative homogeneous trend direction at all the stations" claim is rejected at $1 \%$ significance level. Thus the global trend test is not necessary to perform. PM10 emission trends is seen homogeneous in Alibeyköy, Beşiktaş, Kartal and Sarıyer and for these four stations global trend is tested via $\chi_{\text {trend }}^{2}$ test, for PM10 there is a statistically significant global trend determined at these four stations. For $\mathrm{CO}$ emission, the trends in Aksaray, Alibeyköy, Beşiktaş, Esenler, Kadıköy and Üsküdar where the Mann-Kendall correlation coefficients are significant, are concluded to be heterogeneous. Thus global trend is not inspected. $\mathrm{NO}_{2}$ emission, is seen to have homogeneous positive trend in Beşiktaş, Esenler and Ümraniye.

As Mann-Kendall is a test that ignores the seasonal fluctuations in the data, the seasonal trends in pollutants are tested with seasonal Kendall test. The seasonal Kendall (SK) test results are presented in Table 3. In Seasonal Kendall $(\tau)$ test statistic and Sen's slope estimator is tested with same $\mathrm{H}_{0}$ hypothesis as "there is no seasonal trend". Slope estimators are again calculated using Sen's method as median of slopes in all seasons.

Table 3. Seasonal Kendall (SK) Correlation Coefficients and Sen's Slope Estimators of Air Pollutants (January 2005 -December 2014)

\begin{tabular}{lrrrrr}
\hline \multicolumn{6}{c}{$\mathrm{SO}_{2}\left(\mu \mathrm{g} / \mathrm{m}^{3}\right)$} \\
\hline Stations & $\mathrm{Z}$ & $\mathrm{SK}(\tau)$ & \multicolumn{1}{c}{$\mathrm{Sen}$} & $\chi_{\text {trend }}^{2}$ & $\chi_{\text {homog }}^{2}$ \\
Aksaray & -8.8 & $-0.628^{*}$ & -1.195 & $77.83^{*}$ & 4.59 \\
Alibeyköy & -7.1 & $-0.507^{*}$ & -1.000 & $51.34^{*}$ & 5.45 \\
Beşiktaş & -10.6 & $-0.756^{*}$ & -1.691 & $114.04^{*}$ & 1.24 \\
Esenler & -8.7 & $-0.615^{*}$ & -1.000 & $75.45^{*}$ & 2.02 \\
Kadıköy & -6.9 & $-0.487^{*}$ & -0.500 & $47.94^{*}$ & 6.83 \\
Kartal & -8.8 & $-0.622^{*}$ & -1.333 & $76.90^{*}$ & 3.17 \\
Sarlyer & -5.9 & $-0.413^{*}$ & -0.586 & $34.71^{*}$ & 2.79 \\
Ümraniye & -6.9 & $-0.487^{*}$ & -0.625 & $48.06^{*}$ & 5.26 \\
Üsküdar & -6.4 & $-0.454^{*}$ & -0.667 & $41.38^{*}$ & 6.74 \\
Yenibosna & -9.7 & $-0.687^{*}$ & -1.429 & $94.64^{*}$ & 2.45 \\
\hline \hline
\end{tabular}

Shows the Seasonal Kendall correlation coefficients and Sen's slope estimator are significant with * $1 \%$, with ${ }^{* *} 5 \%$ and with ${ }^{* * *} 10 \%$. 
Table 3. Continued

\begin{tabular}{|c|c|c|c|c|c|}
\hline \multicolumn{6}{|c|}{ PM10 $\left(\mu \mathrm{g} / \mathrm{m}^{3}\right)$} \\
\hline Stations & $\mathrm{Z}$ & $\operatorname{SK}(\tau)$ & Sen & $\chi_{\text {trend }}^{2}$ & $\chi_{\text {hom } o g}^{2}$ \\
\hline Aksaray & 0.1 & 0.007 & 0.00 & 0.01 & 5.31 \\
\hline Alibeyköy & -1.8 & $-0.131^{\star \star *}$ & -1.00 & $3.39^{\star * *}$ & 4.65 \\
\hline Beşiktaş & -5 & $-0.357^{\star}$ & -2.00 & $25.07^{\star}$ & 8.02 \\
\hline Esenler & -1.5 & -0.111 & -1.00 & 2.41 & 4.24 \\
\hline Kadıköy & 0.3 & 0.026 & 0.00 & 0.13 & 3.65 \\
\hline Kartal & -2.8 & $-0.2^{\star}$ & -2.08 & $7.82^{*}$ & 5.78 \\
\hline Sarıer & -3 & $-0.217^{\star}$ & -1.00 & $9.22^{*}$ & 1.23 \\
\hline Ümraniye & 2 & $0.146^{*}$ & 0.75 & $4.21^{\star *}$ & 6.84 \\
\hline Üsküdar & 2.2 & $0.161^{\star}$ & 1.00 & $5.08^{* *}$ & 3.03 \\
\hline Yenibosna & 0 & -0.002 & 0.00 & 0.00 & 2.33 \\
\hline \multicolumn{6}{|c|}{$\mathrm{CO}\left(\mu \mathrm{g} / \mathrm{m}^{3}\right)$} \\
\hline Stations & $\mathrm{Z}$ & $\operatorname{SK}(\tau)$ & Sen & $\chi_{\text {trend }}^{2}$ & $\chi_{\text {homog }}^{2}$ \\
\hline Aksaray & -9.2 & $-0.659^{\star}$ & -63.18 & $84.49^{\star}$ & 1.11 \\
\hline Alibeyköy & -2.3 & $-0.167^{\star *}$ & -10.27 & $5.41^{* *}$ & 2.46 \\
\hline Beşiktaş & -8.3 & $-0.6^{*}$ & -46 & $70.08^{\star}$ & 7.13 \\
\hline Esenler & -3.9 & $-0.281^{\star}$ & -17.83 & $15.42^{*}$ & 10.88 \\
\hline Kadıköy & -6.4 & $-0.459^{\star}$ & -44.38 & $41.03^{*}$ & 6.58 \\
\hline Kartal & ------- & ------- & ------- & ------ & ------ \\
\hline Sarıer & ----- & ------ & ------ & ------ & ----- \\
\hline Ümraniye & ------- & ------- & ------- & ------- & ------ \\
\hline Üsküdar & -3.7 & $-0.267^{\star}$ & -21.40 & $13.82^{*}$ & 5.73 \\
\hline Yenibosna & -0.5 & -0.039 & -2.940 & 0.29 & 14.62 \\
\hline \multicolumn{6}{|c|}{$\mathrm{NO}_{2}\left(\mu \mathrm{g} / \mathrm{m}^{3}\right)$} \\
\hline Stations & $\mathrm{Z}$ & $\operatorname{SK}(\tau)$ & Sen & $\chi_{\text {trend }}^{2}$ & $\chi_{\text {homog }}^{2}$ \\
\hline Aksaray & 0.8 & 0.059 & 0.286 & 0.69 & 9.33 \\
\hline Alibeyköy & 2.4 & $0.176^{\star *}$ & 1 & $6.08^{* *}$ & 16.39 \\
\hline Beşiktaş & 4.7 & $0.341^{\star}$ & 4 & $22.64^{*}$ & 6.07 \\
\hline Esenler & 1.7 & $0.120^{\star * *}$ & 0.824 & $2.83^{\star * *}$ & 7.17 \\
\hline Kadıköy & -3.1 & $-0.222^{\star}$ & -2 & $9.66^{*}$ & 4.08 \\
\hline Kartal & ------- & ------- & ------ & ------ & ------ \\
\hline Sarıyer & ------ & ------ & ------ & ------ & ------- \\
\hline Ümraniye & 3 & $0.219^{*}$ & 1.536 & $9.35^{*}$ & 3.06 \\
\hline Üsküdar & ------- & ------- & ------- & ------ & ------- \\
\hline Yenibosna & . & ------- & ------ & ------- & ---- \\
\hline
\end{tabular}

Shows the Seasonal Kendall correlation coefficients and Sen's slope estimator are significant with ${ }^{*} 1 \%$, with ${ }^{* *} 5 \%$ and with ${ }^{* *} 10 \%$. 
According to this as seen in Table 3, for $\mathrm{SO}_{2}$, at all the stations, seasonal trends are statistically significant and their directions are negative. For PM10 emission, Seasonal Kendall statistics at Aksaray, Esenler, Kadıköy and Yenibosna stations are insignificant. In Alibeyköy, Beşiktaş, Kartal and Sariyer, it is seen that the seasonal trends are significantly negative and at Ümraniye and Üsküdar stations, $t$ is significantly positive.

Among seven stations in which CO emission is investigated, only at Yenibosna station, the seasonal trend is statistically insignificant. At the other six stations, statistically significant negative trends are determined. The strongest decrease in $\mathrm{CO}$ emission is at Aksaray station. The second fastest decrease in $\mathrm{CO}$ emission is at Beşiktaş station. While the decrease of CO, that is a pollutant caused by traffic, is fastest in the districts where the traffic of Istanbul is the busiest, is a pleasing improvement, the decrease trend in other districts being weak shows that the results should be examined in more detail.

When $\mathrm{NO}_{2}$ emission is checked, in Alibeyköy, Beşiktaş, Esenler and Ümraniye seasonal trend with positive direction is determined. It is concluded that there is a significant negative seasonal trend around $22 \%$

However, in order for these values to be valid, the trends calculated at stations for each season separately should be significant and in same direction. For this goal, firstly, the seasonal homogeneity of each pollutant at all stations is done individually via formula (13) and null hypothesis of "Trends in all seasons is in the same direction" is accepted. Also global trend significance is tested. In Table 3 , the homogeneity results are given in $\chi_{\text {hom }}^{2}$ column, and global trend results in $\chi_{\text {trend }}^{2}$. According to this, $\mathrm{SO}_{2}$ emission at all stations concluded to have significant global trends. PM10 has in Alibeyköy, Beşiktaş, Kartal, Sarıyer in all seasons negative homogeneous trend, and in Ümraniye and Üsküdar in all seasons positive homogeneous trend. PM10 has significant global trend at all of these stations.

At the seven stations where CO emission have significant seasonal trend, the trends in between seasons are homogeneous and the global trends are significant. When $\mathrm{NO}_{2}$ emission is considered, including the only station with negative trend Kadıköy station, excluding Aksaray, at all stations homogeneous and global trends can be said to be present.

As much as the existence of the seasonal trend in air pollutants, the trend being same in between stations and seasons is also important. For this reason, using Van Belle-Hughes approach, both between stations and between seasons homogeneity testing is conducted. Homogeneity testing is performed via calculating separately the $\mathrm{Z}_{\mathrm{i}}$ values of each month for all stations. In this calculation there is no continuity correction performed. ${ }^{57}$ While this testing is conducted over ten station for $\mathrm{SO}_{2}$ that has the same significant trend directions at all stations, for PM10 emission it is carried out separately for four stations Alibeyköy, Beşiktaş, Kartal, Sarıyer with negative trends and two

57 Gerard Van Belle- J.P. Hughes, Ibid, p.130. 
stations Ümraniye and Üsküdar with positive trends. Among stations in which CO emission was investigated, among Aksaray, Alibeyköy, Beşiktaş, Esenler, Kadıköy and Üsküdar stations that have significant negative trends, a homogeneity testing is done. For $\mathrm{NO}_{2}$ emission, as there are significant positive trends at Beşiktaş, Esenler and Ümraniye stations, among these stations a homogeneity testing is done. At the Kadıköy station in which $\mathrm{NO}_{2}$ shows decreasing trend, only homogeneity testing in between seasons is performed. The result of these testing is given in Table 3 above. The results of homogeneity testing in between stations and seasons are presented at Table 4 according to formulas (17-21).

According to Table 4; $\mathrm{SO}_{2}$ pollutant has homogeneous trend in between seasons at $1 \%$, while homogeneity between stations can only be reached at $5 \%$. It is concluded that $\mathrm{SO}_{2}$ emission has a homogeneous trend at all the stations both in between seasons and stations. Also there is a constant interaction between seasons and stations. Since the $\chi^{2}$ statistics are insignificant in all of these three homogeneity tests, global trend test is performed and the claim that $\mathrm{SO}_{2}$ emission has global trend between stations is accepted.

Table 4. The Homogeneity Testing of Air Pollutants in Between Seasons and Stations

\begin{tabular}{|c|c|c|c|c|c|c|}
\hline \multirow{3}{*}{ Source } & \multirow{2}{*}{\multicolumn{2}{|c|}{$\begin{array}{c}\mathbf{S O}_{2}\left(\mu \mathrm{g} / \mathrm{m}^{3}\right) \\
\text { Ten Stations with }(-) \\
\text { Slopes }\end{array}$}} & \multicolumn{4}{|c|}{$\operatorname{PM10}\left(\mu \mathrm{g} / \mathrm{m}^{3}\right)$} \\
\hline & & & $\begin{array}{l}\text { Four Stations } \\
(-) \text { Slopes }\end{array}$ & with & $\begin{array}{l}\text { Two Sta } \\
(+) \text { Slope }\end{array}$ & ns with \\
\hline & $\chi^{2}$ & d.f. & $\chi^{2}$ & d.f. & $\chi^{2}$ & d.f \\
\hline Total & 702.89 & 120 & 65.18 & 48 & 19.16 & 24 \\
\hline Homogene. & 62.34 & 119 & 24.98 & 47 & 9.88 & 23 \\
\hline Seasons & 8.94 & 11 & 5.24 & 11 & 8.28 & 11 \\
\hline Stations & $21.80^{* *}$ & 9 & 5.30 & 3 & 0.02 & 1 \\
\hline Season-Stat. & 31.60 & 99 & 14.44 & 33 & 1.58 & 11 \\
\hline Trend & 640.56 & 1 & 40.20 & 1 & 9.28 & 1 \\
\hline
\end{tabular}

${ }^{* *}$ with $5 \%$ significance level $\mathrm{H}_{0}$ accepted 
Table 4. Continued

\begin{tabular}{lcrcr}
\hline & \multicolumn{2}{c}{$\mathrm{CO}\left(\mu \mathrm{g} / \mathrm{m}^{3}\right)$} & \multicolumn{2}{c}{$\mathrm{NO}_{2}\left(\mu \mathrm{g} / \mathrm{m}^{3}\right)$} \\
& $\begin{array}{c}\text { Six Stations with } \\
(-) \text { Slopes }\end{array}$ & $\begin{array}{c}\text { Four Stations with } \\
(+) \text { Slopes }\end{array}$ \\
\hline Source & \multicolumn{1}{c}{$\chi^{2}$} & d.f. & $\chi^{2}$ & d.f. \\
Total & 264.15 & 72 & 73.59 & 48 \\
Homogene. & 72.16 & 71 & 37.80 & 47 \\
Seasons & 9.35 & 11 & 6.42 & 11 \\
Stations & $38.27^{\star}$ & 5 & $21.15^{\star}$ & 3 \\
Season-Stat. & 24.55 & 55 & 10.23 & 33 \\
Trend & 191.99 & 1 & 35.78 & 1 \\
\hline
\end{tabular}

${ }^{*}$ with $1 \%$ significance level $\mathrm{H}_{0}$ rejected

In the same manner as it is seen that the PM10 emission have a homogeneous negative trend at four stations, both between seasons and stations together, and also there is a constant interaction between seasons and stations, global trend test is performed and it is concluded that there is a significant global trend. Similarly, at Ümraniye and Üsküdar stations with positive trends for PM10, as in all three testing the homogeneous trend is concluded, global trend test is performed and at two stations in question, it is concluded that there is a significant positive global trend.

Six stations in which CO emission was investigated, is detected to be homogeneous in between seasons, however the trend between stations is heterogeneous. In this case, trend in at least one station, is significantly different than others.

Also for the six stations in question, it is concluded that there is a constant interaction between seasons and stations. As the trend between stations is heterogeneous, instead of performing a global trend testing, the significance of the seasonal trends of $\mathrm{CO}$ emission should be evaluated separately for each station as it is done in Table 3 above.

While $\mathrm{NO}_{2}$ emission has homogeneous positive trend between seasons at four stations, the trend between stations is seen to be heterogeneous. Thus, for $\mathrm{NO}_{2}$ pollutant, the homogeneity test in between seasons done in Table 3 is sufficient.

\section{Conclusion}

The environmental pollution came forward as a big problem in especially the twentieth century. Thus, all around the world, the environmental indicator are started to be monitored. Turkey stands rather at a low rank among world countries regarding the environment performance index values. Especially the air quality indicators are bad. 
In this study among the air quality indicators gathered and published by IMM, $\mathrm{SO}_{2}$, Particulate Matter $\left(\mathrm{PM}_{10}\right), \mathrm{CO}, \mathrm{NO}_{2}$ data trends are examined monthly in January 2014 to December 2014 period via non-parametric Mann-Kendal test and Seasonal Kendall test. Thus;

- $\quad$ The significant negative Mann-Kendall and seasonal Kendall correlation coefficients are found for $\mathrm{SO}_{2}$ emission at all stations. Also it is determined that the seasonal trend is homogeneous in between both seasons and stations, thus is a significant negative trend. In this case it can be considered that as the usage of natural gas in heating purposes increased in İstanbul-wide in the period of inspection, the $\mathrm{SO}_{2}$ emission is decreased.

- It is determined that PM10 pollutant has a significant negative seasonal trend in Beşiktaş, Esenler, Kartal, Sarıyer, but the trend is rather weak. However, the seasonal trend is in direction of increase in Ümraniye and Üsküdar. It is concluded that the PM10 emission is homogeneous in between seasons and stations, and interaction are constant both stations of positive and negative trends.

- In CO emission, among seven stations that it is monitored according to MannKendall testing, except Yenibosna station, at the other six significant negative trends are found. It is concluded that these trends are heterogeneous in between stations. Whereas in seasonal trend test, while a significant and decreasing homogeneous trend is determined, it is shown that the seasonal trend is heterogeneous in between stations.

- $\quad \mathrm{NO}_{2}$, a very dangerous gas regarding human health, unfortunately has significant positive seasonal trends in Alibeyköy, Beşiktaş, Esenler and Ümraniye.

Air is required for all living things, thus its quality is important for all of us. So the changes of pollutants should always be monitored. The negative trends in pollutants is pleasing, however, especially PM10 and $\mathrm{NO}_{2}$ emissions having positive trends in some stations is a negative development for the goals related to air quality. 


\section{References}

AY, E.F., Balta, M., Çolak, M., Semercioğlu, H., "Hava Kirliliği ve Modellemesi”, Sakarya Üniversitesi, 2010, http://www.sahakk.sakarya.edu.tr/documents/hava\%20kirliligi\%20ve\%20modellemesi\%20II.pdf, Accessed (18.02.2015)

BAYRAM H., “Türkiye'de Hava Kirliliği Sorunu: Nedenleri, Alınan Önlemler ve Mevcut Durum”, Türk Toraks Dergisi August, 6(2), 2005, pp: 159-165

COSUN, F., Karabulut M., "Kahramanmaraş’ta Ortalama, Minimum ve Maksimum Sicaklıkların Trend Analizi”, Türk Coğrafya Dergisi, 53, 2005, pp.41-50

DÜNDAR, C., K. Oğuz, G. Güllü,“Toz Taşınımı Mekanizmalarındaki Farklılıklar: İki Farklı Toz Taşınımı Olayı", 6. Ulusal Hava Kirliliği ve Kontrolü Sempozyumu,, Bildiriler Kitabı, 7-9 Ekim 2015, İzmir, pp.18-28

ELBİR, T. , Müzezzinoğlu, A., Bayram, A., "Evaluation of Some Air Pollution Indicators in Turkey”, Environmental International, 26, 2000, pp.5-10

Environmental Performance Index, 2014, http://epi.yale.edu/epi/country-profile/turkey, Accessed (06.03.2015)

European Commision, http://ec.europa.eu/environment/air/quality/standards.htm, Accessed (12.03.2015)

European Environment Agency www.eea.europa.eu, Accessed (12.03.2015)

GILBERT, R.O., Statistical Methods for Environmental Pollution Monitoring, Von Nostrand Reinhold Company Inc., New York, 1987

GÜMÜŞ O, Alver Şahin, Ü., Onat, B., Özçelik, R., Gedik, E., Solakoğlu, İ., Taş, N., "Marmara Bölgesi Hava Kalitesinin İstatistiksel Yöntemlerle Analizi”, 6. Ulusal Hava Kirliliği ve Kontrolü Sempozyumu, 7-9 Ekim 2015, pp.780-793

HELSEL, D.R. ,R.M. Hirsch, Statistical Methods in Water Resources, Book 4: Hydrologic Analysis and Interpretation, Techniques of Water-Resources Investigations of the United States Geological Survey, 2002

HIRSCH, R.M., "Statistical methods and sampling design for estimating step trends in surface water quality", Water Resources. Research, 24, 1988, pp.493-503

HIRSCH, R.M., Slack, J.R.Smith, R.A. “Techniques of Trend Analysis for Monthly Water Quality Data”, Water Resources Research, 18(1), 1982, pp.107-121

HIRSCH, R.M., Slack, J.R., “A Nonparametric Trend Test for seasonal Data With Serial Dependence”, Water Resources Research, 20(6), 1984, pp.727-732

İstanbul Büyükşehir Belediyesi, İBB, www.ibb.gov.tr/tr-TR

İBB, "İstanbul'da Hava Kalitesi Yönetimi için CBS Tabanlı Bir Karar Destek Sisteminin Geliștirilmesi”, LIFE06-TCY/TR/000283, Teknik Olmayan Rapor, Nisan, İstanbul, 2009

İÇAĞA, Y., Harmancıoğlu, N., "Yeşilırmak Havzasında Su Kalite Eğilimlerinin Belirlenmesi", TMMOB, Türkiye İnşaat Mühendisliği 13. Teknik Kong, 481, 1995, pp.481-497

KALAYCI, S., Kahya, E., "Susurluk Havzası Nehirlerinde Su Kalitesi Trendlerinin Belirlenmesi”, Tr. J. of Engineering and Environmental Science, Tübitak, 1998 ,22, pp.503-514

KALAYCI, S., Kahya, E., “Trend analysis of streamflow in Turkey”, Journal of Hydrology, 289, 2004, pp128144

KENDALL, M. G., (1975), Rank Correlation Methods, Charles Griffin \& Company Limited, London, 2nd ed.

KIROĞLU, G. B., Uygulamalı Parametrik Olmayan İstatistiksel Yöntemler, M.S.Ü. Fen-Edebiyat Fakültesi İstatistik Bölümü, İstanbul, 1996

MALAK U. , Alp, K., "İstanbul Anadolu Yakası Hava Kirliliğinin $\mathrm{PM}_{10}$ ve $\mathrm{PM}_{2.5}$ açısından Değerlendirilmesi”, 6. Ulusal Hava Kirliliği ve Kontrolü Sempozyumu,, 7-9 Ekim 2015, İzmir, pp:515-525

MANN H. B., "Nonparametric Tests Against Trend”, Econometrica, 13(3), 1945, pp. 245-259 
MOZEJKO, Janina, “Detecting and Estimating Trends of Water Quality Parametres", Water Quality Monitoring and Assessment, Ed. K. Voudouris, D. Voutsa, www.intechopen.com, 2012, Accessed (15.03.2015)

NSW Goverment Office of Environment \& Heritage, http://www.environment.nsw.gov.au/AQMS/ dataindex.htm, Accessed (07.03.2015)

ÖNÖZ, B., Bayazıt, M., “The Power of Statistical Tests for Trend Detection”, Turkish Journal of Engineering and Environmental Sciences, TÜBİTAK, 27, 2003, pp:247-251

SCHERTZ, T. L., Alexander, R. B., Ohe, D. J., "The Computer Program Estimate Trend ( Estrend)”, A System For The Detection in Water-Quality Data, U.S. Geological Survey, 1991

SHAPIRO, S. S., Wilk, M. B., "An Analysis of Variance Test for Normality (Complete Samples)", Biometrika, 52(3/4), Dec., 1965, pp 591-611

TAYANÇ, M., Karaca, M., Yenigün, O., "Annual and Seasonal Air Temperature Trend Patterns of Climate Change and Urbanization Effects in Raletion to Air Pollutants in Turkey", Journal of Geophysical Research, 102( D2), 1997, pp.1909-1919

TAYANÇ, Mete, “Türkiyede Hava Kalitesi Modellemesi”, Hava Kirliliği Araştırma Dergisi, 2, 2013, pp.112122

T.C. Başbakanlık Mevzuatı Geliştirme ve Yayın Genel Müdürlüğü, "Hava Kirliliği Değerlendirme ve Yönetimi Yönetmeliği”, http://www.mevzuat.gov.tr/Metin. Aspx? MevzuatKod=7.5.12188\&sourceXmlSearch $=\&$ MevzuatIliski $=0, \quad 2008, \quad$ ErişimTarihi (25.03.2015)

T.C. Çevre ve Şehircilik Bakanlığg Çevre Yönetimi Genel Müdürlügü,"Hava Kalitesinin İnsan Sağlığı Üzerine Olan Etkileri" http://www.csb.gov.tr/gm/cygm/index.php?Sayfa=sayfa\&Tur=banner\&Id=78, Accessed (24.03.2015)

TIAN, J., Fernandez, G.C.J., "Seasonal Trend Analysis of Monthly Water Quality Data”, The Western Users of SAS Software, Los Angeles, US, 1999, pp.1-6

Türkiye İstatistik Kurumu, TUİK, www.tuik.gov.tr

UZGÖREN, E., Yücel, Ö., "Çevre Sorunları Bağlamında Dışsal Ekonomiler ve Ekonomik Etkilerinin Analizi”, Dumlupınar Üniversitesi, Sosyal Bilimler Dergisi, Sayı:3, Kasım, 1999, pp. 97-110

VAN BELLE, Gerald, Hughes, J.P.,"Nonparametric Tests for Trend in Water Quality”, Water Resources Research, Vol:20, No:1, January, 1984, pp.127-136

WONG, R., "A Procedure to Analyze Air Quality Data for the Detection of Linear Time Trends", Air Policy Branch Alberta Environment, Canada, 2010 
